\title{
THE ECOLOGICAL PROBLEMS AND POSSIBLE SOLUTIONS OF BEEKEEPING IN HILLS ANDTERA OF CHTWAN, NEPAL
}

\author{
Suroj Pokhrel $(\mathrm{PhD})^{9}$
}

\begin{abstract}
A general survey accomplished in hills and terai of Chitwan, Nepal in 2004 with an objective to investigate the ecological problems of bee keeping in chitwan and to recommend solutions for its improvement. The survey identifies predators, parasites, diseases, pesticide poisoning, and bee pasture as the key ecological problems in the Hills. Simultaneously, deforestation and pesticide poisoning are the concerned ecological problems in Terai. A very high majority of beekeepers in hills and more than half in Terai faced colony absconding problem in Chitwan. The general survey realized on the need of a special package of program to over come these problems, which include advanced apicultural research and educational activities for the commercialization of beekeeping and advance level crop pollination management in Nepal. For this a clear-cut beekeeping policy and guideline should be developed andshould be implemented.
\end{abstract}

Key words: ecological, absconding, colony status, productivity, species specific

\section{INTRODUCTION}

The Asiatic honeybee, Apis cerana Fab. is adopting by the hill caste community in Chitwan. Bee keeping in the Terai of Chitwan commercialized in the nineties with A. mellifera $L$. (DADO, 2004; DADO, 2005). The total estimated honeybee colony in Chitwan is 7500 (A. mellifera 5500 and A. cerana 2000) (Neupane, 2002). Chitwan seems to be the most potential district enriched with apicultural raw materials, manpower and market. Nectar and pollen as raw materials are available both from forest and from cultivated areas. Development of road infrastructure provides easy bee migration in all the seasons (DADO, 2004; DADO, 2005). However, the technical services, institutional development, honey productivity and market management are not satisfactory. Beekeepers in Chitwan are in hurdele from different managerial, technical, ecological, behavioral and socio-economical problems and policy issues. Among these problems, the ecological problems regarded as the major constraint of beekeeping under Chitwan condition. Thus, it was necessary to know the problems and to suggest the counter measures for the sustainability of beekeeping in Chitwan.

\section{OBJ ECTIVE}

The objective of the study was to investigate the ecological problems of beekeeping and to suggest subsequent recommendations for improving it in Chitwan.

\section{MATERIALS AND METHODS}

The research was conducted in Chitwan district (Inner Terai and the peripheral Mahabharata hills) at central Nepal. The survey on the ecological constraints of A. cerana colonies was carried out in the hills areas of the following VDCs: Chandibhanjyang, Shaktikhor, Korak and Siddhi. Similarly, survey on A. mellifera beekeeping was carried out in the Terai areas: East

\footnotetext{
9 Senior Plant Protection Officer, Dir. of Plant Protection, DOA. Email: surojpokhrel@yahoo.com
} 
Chitwan (Pithuwa, J utepani, Shaktikhor, Chainpur and Padampur VDCs and Ratnanagar Municipality), west Chitwan (Dibyanagar, Sukranagar and Parbatipur VDCs) and Bharatpur municipality. Surveys on the ecological problems of beekeeping in Chitwan were carried during September-October 2004. The survey sites were visited every month and the flora visiting by honeybees both in the cropland and forest were recorded. Information was collected through different methods as shown below. Collected data were tabulated using EXCEL software and necessary tables, graphs and figures were prepared. Means, variance, standard errors, etc. were calculated.

\section{Beekeepers' interview}

A questionnaire was developed, pre-tested, revised and used for collecting necessary information from the beekeepers ( 65 households) to find the ecological constraints of beekeeping in Chitwan district. The information was sought on the following areas:

- Beekeeping, management practices adopted by the beekeepers i.e. (seasonal management, pest and diseases management, pasture management, prevention on pesticide poisoning)

- Ecological problems of beekeeping

- Hive conditions i.e. comb building, brood rearing, hive storage, colony strength, flight and foraging and nest hygiene

- Flora availability and pasture management

The information collected from the survey was verified with available literature.

\section{PRA mapping}

Comparisons and conformation were made by using PRA maps prepared by the A. cerana beekeepers once in Chandibhanjyang and another by the A. mellifera beekeepers in Bharatpur. The diameters of the comparative circles were measured, converted into percentage and the maps were copied in white sheets of papers. These were further verified with beekeepers (18 households) from both hills and plains. Altogether 40 beekeepers (20 from Chandibhanj yang, 20 from Bharatpur) participated in this exercise.

\section{Colony sampling}

Sixty-five hives ( $36 \mathrm{~A}$. cerana and $29 \mathrm{~A}$. mellifera) of beekeepers, having more than 4 colonies of $A$. cerana and 10 colonies of $A$. mellifera and selected randomly, were observed to find the colony status during the study period such as nest hygiene, pest and disease status, honey and pollen storage, brood rearing, comb building, flight and foraging and the estimation of the colony strength.

\section{RESULTS}

A general survey of 65 beekeepers ( 36 in hills and 29 in Terai) was accomplished in 2004 to see the status of apiculture: technology adoption, socioeconomics and environmental factors including major constraints and the potentiality of beekeeping in hills and Terai of Chitwan.

Species of honeybees

Two domesticated honeybees: A. mellifera in Langstroth hive in Terai and A. cerana in 3 different hives (41.1\% in improved, $31.2 \%$ in traditional log and $27.6 \%$ in wall hives) mainly in 
hills, with an mean colony size of 4.4 per household $(N=36)$ in hills and 50.0 per household $(\mathrm{N}=29)$ in Terai were adopted by the beekeepers in Chitwan. The mean colony number of $\mathrm{A}$. mellifera was highest in Bharatpur ( 87.5 colonies/ household) followed by East Chitwan (43.6 colonies/ household) and West Chitwan (22.6 colonies/ household), respectively.

\section{Colony status}

The colony status in both the hills and Terai were not encouraging during September-October 2004. The average number of broods per comb per colony, with both the species in hills and Terai were very low (A. cerana 3.5 vs A. mellifera 2.0 ), including honeycombs ( 0.5 vs 0.4 ), and combs covered by the honeybees (6.0 vs 6.2) per colony. Pollen hording in the nest was also negligible. Some A. cerana (8.3\%) colonies were found infested with V. jacobsoni, while $55.2 \% \mathrm{~A}$. mellifera colonies suffered severely from $\mathrm{T}$. clareae in Terai. Thus, the honeybee colonies were endangered during September-October from parasites; predators and unavailability of food resulting low hive storage (pollen and honey), with reduced brood rearing and poor colony strength. Moreover, in Terai, the highest brood combs were found in A. mellifera nest in Bharatpur fallowed by East and West Chitwan (2.4 vs. 2.0 and 1.6 combs/colony). The honey cells/colony was found higher in East Chitwan than in West Chitwan and in Bharatpur areas ( 0.6 vs. 0.3 and 0.2 comb / colony). It was mainly due to the consumption of honey for higher brood rearing in Bharatpur site than the others. Descended combs were became moldy and infested with wax moth, G. mellonella in several instances. However, the Terai farmers were able to collect them and stored properly in plastic bags or in a metallic bin/tank. Comparatively the A. mellifera colonies in East Chitwan appeared stronger than those in the West Chitwan and Bharatpur area (6.6 vs. 5.9 and 5.9 combs / colony). Pollen storage in Terai was lowest in Bharatpur than in East and West Chitwan (0.1 vs. 0.2 and $0.4 \mathrm{comb} /$ colony). It might be due to the higher pollen consumption and higher brood rearing in Bharatpur than rest of the sites. The mite infestation in A. mellifera colonies was most severe in East Chitwan fallowed by Bharatpur and the least in West Chitwan $169.2 \%$ vs $50.0 \%$ and $37.5 \%$ respondents). The honeybee flight and foraging was highly co-related with the colony strength. Higher the colony strength higher was the collection of food in the nest and high storage was responsible for higher brood rearing. Higher the demand in the nest higher was the rate of foraging. Hence the in-coming and out-going flight at 11.00 AM per 5 minutes per colony was found very low during the survey period. Only $5.6 \% \mathrm{~A}$. cerana and $3.4 \% \mathrm{~A}$. mellifera colonies were having more than 300 bees out-going per 5 minutes. However, $50.0 \% \mathrm{~A}$. cerana and $55.2 \% \mathrm{~A}$. mellifera colonies were having less than 100 workers on outgoing flight per 5 minutes per colony. The remaining $44.4 \% \mathrm{~A}$. cerana and $41.4 \% \mathrm{~A}$. mellifera colonies were of medium size having $100-300$ bees on flight per 5 minutes per colony. Status of the predators was also evaluated during the survey and $15.0 \%$ of the hives with both the bee species were having cockroaches in their hives, $25.0 \%$ of the hives had wax moth, $G$. mellonella, and moldy combs. Hornet, V. orientalis and V. cincta; red/ black wasps, V. ducalis and V. busalis; bee eater, $M$. orientalis and lizard, $H$. flavivirdis were the predators encountered during the survey. Thus, the honeybee colonies were found endangered during September-October from parasites, predators and unavailability of food resulting less hive storage (pollen and honey), with much reduced brood rearing and colony strength. 


\section{ECOLOGICAL PROBLEMS AND ITS EFFECTS}

\section{Predators}

The predators, hornet, V. orientalis and V. cincta; red/ black wasps, V. ducalis and V. busalis; bee eaters, M. orientalis; king crow, D. macrocercus; predatory ants, $M$. indicum and $C$. compressus; frog, B. melanostictus; cockroach, P. americana; wax moth, G. mellonella and A. grisella; pine martin, M. flavigula; spiders, N. kuhlii and P. aurichalcea; garden lizard, Calotes versicolor were the serious bee predators in Chitwan. Many beekeepers managed them by their traditional methods: nest burning and hitting with a wooden flapper against the predatory wasps; use Ghanti (bell) or thorny branches of plants on the side of the log/ wall hive or use of scare crow or guarding during the night against pine martin, M. flavigula; use of hive stand and the water cups at the base against predatory ants, $M$. indicum and $C$. compressus and use of taller iron stand against predatory frogs, B. melanostictus; physical control of cockroach, P. americana and lizard, H. flavivirdis; bottom board cleaning against wax moths, G. mellonella and A. grisella; drum beating or watching or use of cat pole against bee eater, M. orientalis; and king crow, D. macrocercus and removal of spider web with broom were the common practices (Annex 1).

Red and black wasps, V. ducalis and V. busalis were number one predators (91.7\%) followed by hornet, V. orientalis and V. cincta $(66.7 \%)$; pine martin, M. flavigula (38.9\%); predatory ants, M. indicum (33.3\%); cockroach, P. americana (25.0\%); wall lizard, H. flavivirdis (16.7\%) and king crow, D. macrocercus (16.7\%) in the hills. Spiders, N. kuhlii; cockroach, P. aurichalcea and wax moths, A. grisella were other minor predatory problems. However, in Terai A. mellifera were seriously hampered by hornets, V. orientalis and V. cincta $(82.6 \%$; red and black wasps, V. ducalis and V. busalis (72.4\%); bee eaters, M. orientalis $(62.0 \%$; predatory ants, M. indicum and C. compressus (24.1\%) and frogs, B. melanostictus (20.7\%). Moreover, cockroach, P. americana; wax moth, G. mellonella and A. grisella; spiders, N. kuhlii and P. aurichalcea and lizards, $H$. flavivirdis were also harmful predators (Annex 1 ). Among these predators hornet, $\mathrm{V}$. orientalis and V. cincta; red and black wasps, V. ducalis and $V$. busalis; bee eaters, $M$. orientalis and frog, $B$. melanostictus were active in rainy season and ants, $M$. indicum and $C$. compressus were re-active in summer. However, spiders, $N$. kuhlii and P. aurichalcea; lizard, H. flavivirdis; cockroach, P. americana and pine martin, M. flavigula were active around the year.

\section{Parasites}

The brood parasitic mites, T. clareae on A. mellifera and V. jacobsoni on A. cerana were the most serious bee parasites in Chitwan. Mites were most severe in Terai $(96.6 \%)$ then in hills (9.2\%). A. mellifera beekeepers in Terai used apistan, sulphur dust and formic acid against them. Some beekeepers adopted biological control through controlling queen for 21 days to manage the mites (Annex 2). However, the respondents were not fully satisfied with the efficacy of these available practices.

\section{Diseases}

Paralysis and death of adult bees due to unknown causes, foul brood caused by Bacillus spp and nosema caused by Nosema apis Zander were important diseases of honeybees in Chitwan (Annex 2). Paralysis of adult bees is occurring during J une-J uly and J anuary-March, severe 
deaths of adults during June-July, foul brood and nosema during July-August. However, beekeepers were unable to control them.

\section{Pesticide poisoning}

Pesticide poisoning was reported by $91.7 \%$ respondent in hills and $100 \%$ in Terai beekeepers. Poisoning of bees from insecticides was in higher frequency in Terai than in hill however, poisoning in hills was severe with $16.6 \%$ respondents and $24.1 \%$ in Terai. Severe poisoning in Terai was mainly due to water and pasture contamination. It was most severe in East Chitwan

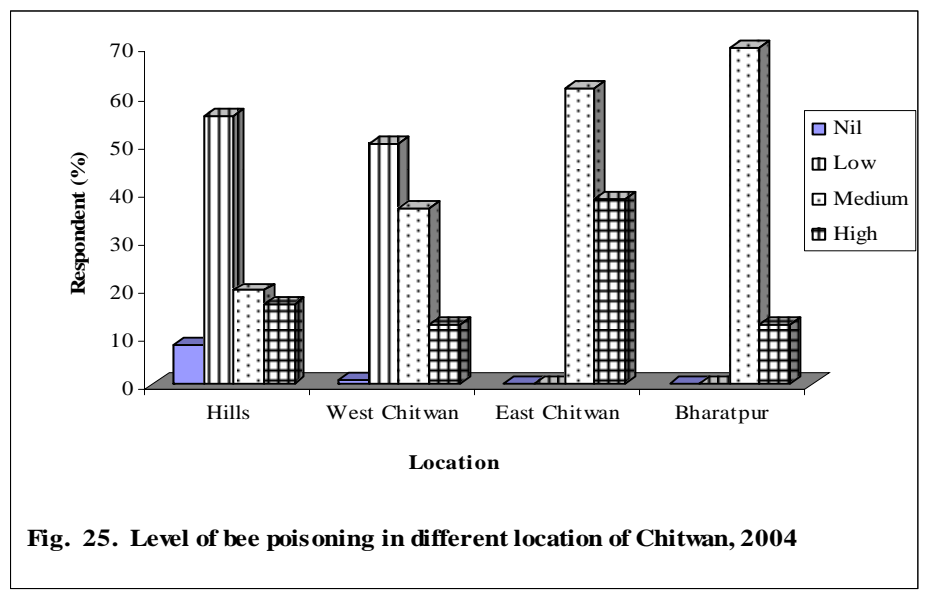
(38.5\%) than in West (12.5\%) and Bharatpur area (12.5\%). The proportion of high, medium and low poisoining of honeybee colonies wasl:1.2:3.3 in hills and 1:2.6:0.6 in Terai. Moreover, the proportion in West Chitwan was 1:2.9:4.0, East Chitwan1:1.6:0 and Bharatpur 1:7:0. Thus, the poisoning problem was most severe in Terai than in hills and was most severe in East Chitwan than in West Chitwan and Bharatpur area (Fig. 1).

Mandarin orange, Citrus reticulate Balanco; litchi, Litchi chinensis Sonner; buckwheat, Fagopyrum esculentum Moench; maize, Zea mays L.; beans, Phaseolus vulgaris L.; peas, Pisum sativum L.; coriander, Coriandrum sativum L. and broad leaf mustard, Brassica juncea sub sp. Rugosa (Roxb.) Prain were some of the bee crops grown in Chitwan. Various pesticides are used by farmers for crop protection at different doses and frequencies both in the hills and Terai of Chitwan. Methyl parathion (25\% respondent), dimethoate (25\%), deltamethrin (25\%) and cypermethrin (19.4\%) were the common pesticides used in crops in the hills. However, endosulfan $(65.5 \%)$, methyl parathion $(27.6 \%)$, carbofuran $(17.2 \%)$, deltamethrin $(13.8 \%)$, stampade $(10.3 \%)$, malathion $(6.9 \%)$, dichlorvos $(6.9 \%)$, dimethoate $(3.4 \%)$ and phorate (3.4\%) were common in Terai. Some respondents, $5.6 \%$ in hills and $31.0 \%$ in Terai were unknown what they sprayed on their bee crops. The average frequency of application of these pesticides was 1-4 times and the average dose was $1 \mathrm{ml}$ in case of deltamethrin, $2 \mathrm{ml}$ of other EC formulations, 2-3g of WP formulations per liter of water and $30 \mathrm{~kg}$ of granules / ha (Annex 3).

\section{Lack of bee pasture and pasture reduction}

The cropped area of bee pasture especially mustard, Brassica spp. in Chitwan has been reduced by $50 \%$ in last ten years. However the coverage of buckwheat, maize and beans is increasing year after year. Reduction of pasture due to deforestation was reported $19.4 \%$ respondent in hills and $37.9 \%$ in Terai. Lack of bee pasture was more severe in Terai $(37.9 \%)$ than in hills (19.4\%) (Annex 4). Cutting down of the Shisoo, Dalbergia sissoo Roxb. tree from the Churiya range seriously damaged the habitat of the important bee flora (rudilo, Pogostemon glaber Benth.) which was an important source of nectar. The bee pasture is limited in Bharatpur area (town) than in rural Terai (East and West Chitwan). 


\section{Colony absconding}

Almost beekeepers (94.4\%) in hills and more than half $(58.5 \%)$ in Terai faced absconding problem (Annex 5). The main cause of A. cerana absconding was its behavior $(75.0 \%$, however it was influenced by food/pasture deficiency (69.4\%), pesticide poisoning (30.6\%), predators pressure $(22.2 \%)$, parasitic pressure $(11.1 \%)$, rain water in the hive $(11.1 \%)$ and summer heat $(5.6 \%)$. Moreover, in Terai pesticide poisoning $(37.9 \%$, poor feeding management and pasture deficiency $(34.5 \%)$ and parasitic mites $(20.7 \%)$ were the major ecological releted causes of $A$. mellifera absconding (Annex 6$)$. The colonies of A. mellifera absconded during J uly-September in Terai, and A. cerana in J une-August in hills.

\section{POLICY PROBLEM}

There is not any legal clear-cut national beekeeping policy in Nepal. Sharing the bee pasture, conservation of the bee flora in both cropland and natural forest, preventing pesticide poisoning, developing bee pasture and stopping deforestation are the major issues, which can settle the conflicts between beekeepers and crop growers and established understanding between beekeepers and forest owner. Lack of organizational development (17.2\%) rises conflicts especially for pasture use (17.2\%) between the farmers of East and West Chitwan, farmers between inter districts, between beekeepers and the crop growers, etc. Lack of national policy and program (10.3\%) was the important cause of these conflicts.

Beekeepers from the hills and Terai have suggested in many ways to overcome the ecological problems of beekeeping in Chitwan. Development of bee pasture, controlling deforestation, management of pest and diseases and preventing pesticide poisoning could control colony absconding, raise the colony strength and helps to have higher honey production. Beekeepers also suggested for the advance level crop pollination and problem solving trainings and demanded for the declaration of beekeeping policy and guideline from Government of Nepal (GON). GON should attempt to control bee poisoning through legislative initiative (Annex-7).

\section{DISCUSSION}

Beekeepers adopted A. mellifera in Terai and A. cerana in in hills. The average colony size in the hills was 4.4 and in Terai 50.0 per household. Chepang and the hill caste community are adapting $A$. cerana in traditional hives in hills (Devkota, 2003). A. mellifera was multiplied during nineties and distributed through both farmers to farmers (59\%) and from DADO to farmers (41.0\%) in nineties in Terai (DADO, 2004; DADO, 2005). The total estimated bee colonies were 5,500 A. mellifera and 2,000 A. cerana in Chitwan (Neupane, 2002).

The respondents recalled various ecological reasons of decreasing colony numbers and honey productivity in the hills. Their responses on declining bee colonies and honey productivity were declining pasture $(22.2 \%$ and $27.8 \%)$, absconding $(33.3 \% 13.8 \%)$ and pesticide poisoning $(25.0 \%, 13.8 \%)$. Others included diseases, parasites and predators pressure and small colonies. On the contrary, as per their responses the number of colonies $(62.1 \%)$ and honey production (62.1\%) of A. mellifera in Terai increased, which was mainly due to colony division $(55.1 \%$ and $17.2 \%$ ) and seasonal management (feeding and migration) (13.7\% and $31.0 \%$ ). Moreover, they responded increasing trend of honey productivity in Terai, because of adopting larger size colonies $(24.1 \%)$, rearing many colonies $(17.2 \%)$ and queen management $(13.8 \%)$. The result agreed with DADO (2004). DADO (2004) found increased colony number from 25 to 3700 and 
increased annual honey production from 13 to $98 \mathrm{mt}$ during the last 10 years in Chitwan. More over the ecological problems are also severe in Terai.

The colony status in both the hills and Terai were not encouraging during September-October. The brood rearing, honey/ pollen storage, comb covering and the foraging were very low in both hills and Terai. Some A. cerana (8.3\%) colonies were infested with V. jacobsoni and $55.2 \% \mathrm{~A}$. mellifera colonies suffered severely due to $\mathrm{T}$. clareae.

The predators: hornets, V. oriental is and V. cincta; red and black wasps, V. ducalis and V. busalis; bee eaters, M. orientalis; king crow, D. macrocercus; predatory ants, M. indicum and C. compressus; frog, B. melanostictus; cockroach, P. americana; wax moth, G. mellonella and A. grisella; pine martin, M. flavigula; spiders, N. kuhlii and P. aurichalcea; garden lizard, C. versicolor; lizard, $\mathrm{H}$. flavivirdis and the brood parasitic mites, clareae and V. jacobsoni were the serious biological problems of honeybees in Chitwan. Many beekeepers managed them from traditional methods: nest burning and beating with a wooden flapper against hornets and the red and black wasps, use of Ghanti (bell) or thorny branches of plants on the side of log/ wall hives or use of scare crow or guarding during night against pine martin, use of hive stands and water cups at the base against predatory ants and use of taller hive stands against predatory frog, physical control of cockroach and lizard, bottom board cleaning against wax moths, drum beating or watching or use of cat pole against bee eater and king crow, removal of spider web with broom. Chemicals such as: apistan, sulphur dust, formic acid including queen control in Terai are practiced against the brood mites. Paralysis and death of adult bees, foul brood and nosema disease were other important problems but beekeepers were not aware of them. The parasitic mite was found by Baker and Delfinado in 1976 from bee nests in Nepal (Shrestha, 1996). Shrestha (1996) identified Thai sac brood, European fowl brood, V. jacobsoni and T. clareae from A. cerana and A. mellifera colonies in Kathmandu. Shrestha and Shrestha (1997) reported Thai Sac Brood virus disease of A. cerana in mid hills, Nepal. Wilde et al. (2000) found apistan, most effective against brood mites. Shrestha (2001) also found the parasitic mites $T$. clareae in brood cells and adult bees and $F$. galleriella in deserted combs as a serious problem on A. dorsata honeybee in Chitwan, Nepal.

Deforestation and pesticide poisoning were the major ecological problems of honeybee in Terai resulting absconding $(94.4 \%$ respondents with $38.2 \% A$. cerana colonies and $58.6 \%$ respondents with $3.7 \% \mathrm{~A}$. mellifera colonies) and low production potential (A. cerana $22.2 \%$ ). The main causes of $A$. cerana absconding were its behavior (75.0\%) influence by food/ pasture deficiency $(69.4 \%)$, pesticide poisoning $(30.6 \%)$, predators pressure $(22.2 \%)$, parasites pressure $(11.1 \%)$, rain water $(11.1 \%)$, and summer heat $(5.6 \%)$ in hills. However, in Terai, pesticide poisoning $(37.9 \%)$, pasture deficiency $(34.5 \%)$ and parasitic mite $(20.7 \%)$ were the ecological causes of A. mellifera absconding. Tokuda (1924), Tokuda (1935), Roepke (1930), Kellog (1941), Sakagami (1960a) and Sakagami (1960 b) also reported swarming and absconding of A. cerana colonies as serious problem, hindering the commercial beekeeping.

\section{CONCLUSION AND RECOMMENDATION}

Beekeepers in Chitwan are adopting two domesticated honeybee species: A. cerana in hills and A. mellifera in Terai, with small average colony number (4.4 per household in hills and 50.0 in Terai). There existed several ecological problems limitating beekeeping industry in Chitwan. Declining bee crops, deforestation, poisoning, parasitic and predatory pressure are responsible for poor brood rearing, reduced colony strength, low pollen storage and poor incoming and out-going flight with higher mite infestation in the nest and low productivity of 
the hive products. All these shorts of problems were most severe in both hills and Terai. Thus, this study realized on the need of a clear-cut beekeeping policy and guidelines from the Government of Nepal to overcome the associated problems of beekeeping. It is also important to have a special program for the promotion of A. cerana beekeeping in hills, which include educational activities, technical supports; breed improvement and extension of low cost technology. Commercialization of beekeeping with A. mellifera in Terai needs advance apicultural research and extension mechanism including crop pollination and beekeeping training with a secured honey market.

\section{REFERENCES}

Devkota, K.H., 2003. Economic impact of apiculture in Nepal (a case study of J utpani VDC),

DADO, 2004. An overview of beekeeping and honey production in Chitwan district, Nepal. DADO, Chitwan, Nepal, pp27.

DADO, 2005. Barsik Krishi Bikas Karyakram Tatha Tathyanka. 2004. DADO, Chitwan, Nepal. 124 pp. Kellog, C.R. 1941. Some characteristics of the oriental honeybee Apis indica F. in China. J. Econ. Entomol., 34:717-779.

Neupane, K. R., 2002. Byabasaik Mauri Palanma Chitwan J illa Agrasthanma. Chitwan Mahotsov Smarika Chitwan. pp.31. (in Nepali).

Roepke, W., 1930. Beobachtungen an indishen Honigbienen insbesondere on Apis dorsata Meded Landbounwhooge-School Wageninger. 34:1-28.

Sakagami, S. F., 1960a. Preliminary report on the specific difference of behavior and other ecological characters between European and J apanese honeybee. Acta Hymenopterologica 1:171-198.

Sakagami, S.F., 1960b. Two opposing adaptations in the post-stinging response of the honeybees. Studies on the J apanese honeybees. VIII. Evol. 14:29-40.

Shrestha, S., 1996. Study on honeybee diseases in Kathmandu valley. Master's Thesis. Tribhuvan University, Institute of Science. Kirtipur, Kathmandu, Nepal.

Shrestha, J. B., 2001. Investigation of the parasitic mite, Tropilaelaps clareae Delfinado and Baker, and its host, Apis dorsata Fab., in Chitawan Nepal. Master's Thesis. Tribhuvan University, Institute of Agriculture and Animal Science. Rampur, Chitwan. 79 pp.

Shrestha, K.K. and N. C. T. D. Shrestha, 1997. Study on Thai sac brood virus disease of A. cerana in Nepal. In: Proceedings of 4th Asian Apicultural International Conference. March 23-28, 1998. Oxford and IBH publishing Co. Pvt. Ltd., New Delhi, pp60-63.

Tokuda, Y., 1924. Studies on the honeybee, with special reference to the J apanese honeybee. Tr. Sapporo Nat. Hist. Soc., 9:1-6.

Tokuda, Y., 1935. Studies on the honeybee, with special reference to the J apanese honey bee. Bull. Zoo. Tech. Exp. Sta. Chiba Shi, Japan.

Wilde, J., J. Woyke, K.R. Neupane and M. Wilde, 2000. Comparative evaluation tests of different methods to control Tropilaelaps clareae, a mite parasite in Nepal. In: Proceedings of the 7th International Conference on Tropical Bees and 5th AAA Conference. March 19-25, 2000. Chaing Mai, Thailand, pp249-251. 


\section{ANNEXS}

Annex 1: Predators of honeybees in Chitwan, 2004

\begin{tabular}{|c|c|c|c|c|c|c|}
\hline \multirow{2}{*}{ SN } & \multirow{2}{*}{ Predators } & \multirow{2}{*}{ Season } & \multicolumn{3}{|c|}{ Respondent (\%) } & \multirow{2}{*}{$\begin{array}{l}\text { Control } \\
\text { measure } \\
\text { adopted }\end{array}$} \\
\hline & & & Hills & Terai & Total & \\
\hline 1 & Hornets, Vespa orientalis L., V. cincta F. & May-Oct & $\begin{array}{l}66.7 \\
(24)\end{array}$ & $\begin{array}{l}82.6 \\
(24)\end{array}$ & $\begin{array}{l}70.8 \\
(46)\end{array}$ & $\begin{array}{l}\text { Nest burning, } \\
\text { beating }\end{array}$ \\
\hline 2 & $\begin{array}{l}\text { Red wasp, V. ducalis Smith } \\
\text { Black wasp, V. busalis Smith }\end{array}$ & May-Oct & $\begin{array}{l}91.7 \\
(33)\end{array}$ & $\begin{array}{l}72.4 \\
(21)\end{array}$ & $\begin{array}{l}86.2 \\
(56)\end{array}$ & $\begin{array}{l}\text { Nest burning, } \\
\text { beating }\end{array}$ \\
\hline 3 & Pine martin, Martes flavigula & Year round & $\begin{array}{l}38.9 \\
(14)\end{array}$ & - & $\begin{array}{r}21.5 \\
(14)\end{array}$ & $\begin{array}{l}\text { Ghanti, scare } \\
\text { crow, watching, } \\
\text { thorny branches }\end{array}$ \\
\hline 4 & $\begin{array}{l}\text { Ants, Monomorium indicum Morell } \\
\text { Camponotus compressus F. }\end{array}$ & May-J ul & $\begin{array}{l}33.3 \\
(12)\end{array}$ & $\begin{array}{r}24.1 \\
(7)\end{array}$ & $\begin{array}{l}29.2 \\
(19)\end{array}$ & Hive stand \\
\hline 5 & Cockroach, Periplanata americana & Year round & $\begin{array}{r}25.0 \\
(9)\end{array}$ & $\begin{array}{l}7.0 \\
(2)\end{array}$ & $\begin{array}{l}16.9 \\
(11)\end{array}$ & Physical method \\
\hline 6 & Wall Lizard, Hemidactylus flavivirdis & Year round & $\begin{array}{r}16.7 \\
(6)\end{array}$ & - & $\begin{array}{r}9.2 \\
(6)\end{array}$ & Beating \\
\hline 7 & $\begin{array}{l}\text { Bee eater, Merops orientalis Latham } \\
\text { Kingcrow, Discrurus macrocercus Vielillot }\end{array}$ & Rainy & $\begin{array}{r}16.7 \\
(6)\end{array}$ & $\begin{array}{l}62.0 \\
(18)\end{array}$ & $\begin{array}{l}36.9 \\
(24)\end{array}$ & $\begin{array}{l}\text { Watching, katpol, } \\
\text { drum beating }\end{array}$ \\
\hline 8 & $\begin{array}{l}\text { G. wax moth, Galleria mellonella L. } \\
\text { S. wax moth, Achroia grisella F. }\end{array}$ & June- Aug & $\begin{array}{l}8.3 \\
(3)\end{array}$ & $\begin{array}{l}7.0 \\
(2)\end{array}$ & $\begin{array}{l}7.7 \\
(5)\end{array}$ & Hive clearing \\
\hline 9 & $\begin{array}{l}\text { Spider webs, Nuphilia kuhlii } \\
\text { Protaetia aurichalcea F. }\end{array}$ & Year round & $\begin{array}{l}5.6 \\
(2)\end{array}$ & $\begin{array}{l}7.0 \\
(2)\end{array}$ & $\begin{array}{l}6.2 \\
(4)\end{array}$ & $\begin{array}{l}\text { Removing the } \\
\text { webs }\end{array}$ \\
\hline 10 & Garden lizard, Calotes versicolor & Apr-J un & $\begin{array}{l}2.8 \\
(1)\end{array}$ & $\begin{array}{l}3.4 \\
(1)\end{array}$ & $\begin{array}{l}3.1 \\
(2)\end{array}$ & - \\
\hline 11 & Frog, Bufo melanostictus $\mathrm{S}$. & Rainy & - & $\begin{array}{r}20.7 \\
(6)\end{array}$ & $\begin{array}{l}9.2 \\
(6)\end{array}$ & Hive stand (tall) \\
\hline
\end{tabular}

Figures in parenthesis are the respondents' number.

Annex 2: Disease and parasite problems in beekeeping in Chitwan, 2004

\begin{tabular}{|c|c|c|c|c|c|c|}
\hline \multirow[t]{2}{*}{ SN } & \multirow[b]{2}{*}{ Parasites } & \multirow{2}{*}{ Season } & \multicolumn{3}{|c|}{ Respondents \% } & \multirow{2}{*}{$\begin{array}{l}\text { Control measure adopted } \\
\text { by the respondents }\end{array}$} \\
\hline & & & Hills & Terai & Total & \\
\hline 1 & $\begin{array}{l}\text { Mites: Varroa jacobsoni Oud. } \\
\text { Tropilaelaps clareae Delfinado } \\
\text { and Baker }\end{array}$ & $\begin{array}{l}\text { Year round } \\
\text { Year round }\end{array}$ & $\begin{array}{r}16.7 \\
(6)\end{array}$ & $\begin{array}{l}96.6 \\
(28)\end{array}$ & $\begin{array}{r}9.2 \\
(6) \\
43.1 \\
(28)\end{array}$ & $\begin{array}{l}\text { Apistan, sulphur dust, formic } \\
\text { acid and queen control }\end{array}$ \\
\hline 2 & Nosema, Nosema apis Zander & J une- J uly & $\begin{array}{l}2.8 \\
(1)\end{array}$ & $\begin{array}{l}6.9 \\
(2)\end{array}$ & $\begin{array}{l}4.6 \\
(3)\end{array}$ & Not known \\
\hline 3 & Paralysis, virus & $\begin{array}{l}\text { J une-J uly, } \\
\text { J an-March }\end{array}$ & $\begin{array}{l}5.6 \\
(2)\end{array}$ & $\begin{array}{l}41.4 \\
(12)\end{array}$ & $\begin{array}{r}21.5 \\
(14)\end{array}$ & Not known \\
\hline 4 & Adult's death & J une- J uly & $\begin{array}{r}13.9 \\
(5)\end{array}$ & - & $\begin{array}{l}7.7 \\
(5)\end{array}$ & Not known \\
\hline 5 & Foul brood, Bacillus spp. & Year round & - & $\begin{array}{r}27.6 \\
(8)\end{array}$ & $\begin{array}{r}12.3 \\
(8)\end{array}$ & Antibiotic \\
\hline
\end{tabular}

Figures in parenthesis are the respondent numbers. 
Annex 3: Common pesticides and their uses on bee crops in Chitwan, 2004

\begin{tabular}{l|l|r|r|l|r|r}
\hline \multirow{2}{*}{ SN } & Pesticide & \multicolumn{2}{|c|}{ Respondents (\%) } & Terai & Treated crops & Used \\
\cline { 2 - 5 } (times)
\end{tabular}

Figures in parenthesis are the respondent numbers.

Annex 4: Deforestation/ pasture lacking problem on beekeeping in Chitwan, 2004

\begin{tabular}{|c|c|c|c|c|c|c|c|}
\hline \multirow[t]{3}{*}{ SN } & \multirow[t]{3}{*}{ Problems } & \multicolumn{5}{|c|}{ \% respondent having problems } & \multirow{3}{*}{$\begin{array}{l}\text { Grand } \\
\text { Total }\end{array}$} \\
\hline & & \multirow[t]{2}{*}{ Hill } & \multicolumn{3}{|l|}{ Terai } & \multirow[t]{2}{*}{ Total } & \\
\hline & & & West & East & Bharatpur & & \\
\hline 1 & $\begin{array}{l}\text { Deforestation/ Pasture } \\
\text { lacking }\end{array}$ & $\begin{array}{r}19.4 \\
(7) \\
\end{array}$ & $\begin{array}{r}37.5 \\
(5) \\
\end{array}$ & $\begin{array}{r}30.8 \\
(8) \\
\end{array}$ & $\begin{array}{r}50.0 \\
(4) \\
\end{array}$ & $\begin{array}{l}37.9 \\
(11) \\
\end{array}$ & $\begin{array}{l}27.7 \\
(18) \\
\end{array}$ \\
\hline
\end{tabular}

Figures in parenthesis are the respondent numbers

Annex 5: Absconding of honeybee colonies at different locations in Chitwan, 2004

\begin{tabular}{|c|c|c|c|c|c|c|c|}
\hline \multirow{3}{*}{ SN } & \multirow{3}{*}{ Behavior } & \multicolumn{6}{|c|}{ Respondents having the problem (\%) } \\
\hline & & \multirow[b]{2}{*}{ Hills } & \multicolumn{4}{|l|}{ Terai } & \multirow{2}{*}{$\begin{array}{l}\text { Grand } \\
\text { Total }\end{array}$} \\
\hline & & & West & East & Bharatpur & Total & \\
\hline 1 & Absconding & $94.4(34)$ & $62.5(5)$ & $46.2(6)$ & $75.0(6)$ & $58.6(17)$ & $78.5(51)$ \\
\hline
\end{tabular}

Figures in parenthesis are the respondent numbers. 
Annex 6: Causes of absconding in honeybees at different locations of Chitwan, 2004

\begin{tabular}{|c|c|c|c|c|c|c|c|}
\hline \multirow[b]{2}{*}{ SN } & \multirow[b]{2}{*}{ Cause } & \multirow[b]{2}{*}{ Hill } & \multicolumn{4}{|c|}{ Respondents (\%) } & \multirow[b]{2}{*}{ Mean } \\
\hline & & & West & East & $\begin{array}{l}\text { Bharatp } \\
\text { ur }\end{array}$ & Total & \\
\hline 1. & $\begin{array}{l}\text { Food/pasture } \\
\text { deficiency }\end{array}$ & $69.4(25)$ & $37.5(3)$ & $23.1(3)$ & $50.0(4)$ & $34.5(10)$ & $53.8(35)$ \\
\hline 2. & Behavior & $75.0(27)$ & & & & & $41.5(27)$ \\
\hline 3. & Rain water entrance & $11.1(4)$ & - & & $\begin{array}{ll}- \\
\end{array}$ & & $6.2(4)$ \\
\hline 4. & Summer heat & $5.6(2)$ & - & - & - & - & $3.1(2)$ \\
\hline 5. & Bad hives & 47.2 (17) & - & - & - & - & $26.2(17)$ \\
\hline 6. & SARUN (ritual belief) & $16.7(6)$ & & & & & $9.2(6)$ \\
\hline 7. & Parasites & $11.1(4)$ & $12.5(1)$ & $23.1(3)$ & $37.5(3)$ & $20.7(6)$ & $15.4(10)$ \\
\hline 8. & Predators & $22.2(8)$ & 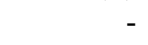 & 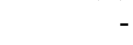 & - & - & $12.3(8)$ \\
\hline 9. & Physical disturbances & $2.8(2)$ & & & - & -- & $3.1(2)$ \\
\hline 10. & Comb harvesting & $8.3(3)$ & & & & & $4.6(3)$ \\
\hline 11. & Pesticide poisoning & 30.6 11) & $25.0(2)$ & $46.2(6)$ & $37.5(3)$ & $37.9(11)$ & $44.6(29)$ \\
\hline 12. & Weak colony & & $50.0(4)$ & $30.8(4)$ & $25.0(2)$ & $34.5(10)$ & $15.4(10)$ \\
\hline 13. & Robbing & $2.8(1)$ & & & $12.5(1)$ & $3.4(1)$ & $3.1(2)$ \\
\hline 14. & Old queen & & $12.5(1)$ & & & $3.4(1)$ & $1.5(1)$ \\
\hline
\end{tabular}

Note: Absconding season: A. mellifera Jul-Sept.; A. cerana J un-Aug.

Figures in parenthesis are the respondent numbers.

Annex 7: Suggestions provided by the beekeepers in Chitwan, 2004

\begin{tabular}{l|l|l|l}
\hline \multirow{2}{*}{ SN } & \multirow{2}{*}{ Suggestions } & \multicolumn{2}{|c}{ Respondents (\%) } \\
\cline { 3 - 4 } 1 & Training on swarm hiving and absconding control & $13.9(5)$ & \\
\hline 2 & Advance training on pollination and management & & $13.8(4)$ \\
\hline 4 & Mass campaigning for hornet/ wasps control & $2.8(1)$ & \\
\hline 5 & Prohibit poison and take precaution & $2.8(1)$ & $13.8(4)$ \\
\hline 6 & Technical help, diagnostic lab, treatment and fallow up & & $27.6(8)$ \\
\hline 7 & Pasture development, management & & $20.7(6)$ \\
\hline 8 & Interaction between beekeepers and crop growers & & $24.1(7)$ \\
\hline 9 & Policy declaration & $2.8(1)$ & $6.8(2)$ \\
\hline
\end{tabular}

Figures in parenthesis are the respondent numbers. 